\title{
Lepadarg IIIn
}

ICONICITY IN ANCIENT LANGUAGES. A CASE STUDY OF KA-RA IN GREEK ICONICIDADE EM LÍNGUAS ANTIGAS. UM ESTUDO DE CASO DE KA-RA EM GREGO 


\title{
Iconicity in ancient languages. A case study of KA-RA in Greek
}

\section{Maria Mertzani ${ }^{1}$}

\begin{abstract}
The study looks at the iconicity, phonemic and graphemic, of the historical marker KA-RA since Mycenaean Greek, following current research paradigms of psycholinguistics. Its syllables (KA, RA) are examined in relation to the shape of its referents, mapped into roundness overall. Concerning KA, the study shows that both the phoneme and grapheme refer to round and angular/linear real-world referents, an outcome that agrees with previous research. In addition, KA-RA is shown to be culturally constructed, manifested in i.e., art designs that have been preserved and expressed in a similar fashion across civilizations, especially in the worship of Mother Earth.
\end{abstract}

Keywords: symbolism; language iconicity; non-arbitrariness; Greek; ancient script.

Resumo: A pesquisa analisa a iconicidade, fonêmica e grafêmica, do marcador histórico KA-RA desde o grego micênico, seguindo os paradigmas atuais da pesquisa psicolingüística. As sílabas (KA, RA) são examinadas em relação à forma dos seus referentes, mapeadas em objetos redondos. Em relação à $K A$, a pesquisa mostra que o fonema e grafema referem-se a objetos redondos e angulares/lineares, um resultado de acordo com pesquisas anteriores. Além disso, o KA-RA aparece como construído culturalmente, manifestado em desenhos de arte que foram preservados e expressos de formas semelhantes através das civilizações, especialmente no culto da Mãe Terra.

Palavras-chave: simbolismo; iconicidade da língua; não-arbitrariedade; grego, escrita antiga.

\section{INTRODUCTION}

During my post-doc study (February 2014 - March 2016) on the symbolism of closed phonology of natural languages (spoken and signed) in the Federal University of Pelotas (UFPel), Pelotas-RS, Brasil, I examined the symbolism of Mycenaean Greek (Linear B) KA syllable in a corpus of 84 words based on Tselentis (2012). Phonemically, the specific syllable corresponds to the velar consonants kappa, gama, chi, and graphemically, is a round symbol, the encircled cross (Figure 1).

This examination was based on a growing research that challenges the Saussurean arbitrariness of language, demonstrating a possible connection between form, meaning and real-world referents through symbolism when content-free units convey meaning in certain linguistic contexts (HINTON, NICHOLS and OHALA, 1994). In this study, symbolism is twofold, for language is materialised phonologically by speaking, and graphemically in writing (GENETTE, 1995). In fact, the phonemes and graphemes are consciously imitative of schematic structures that are grounded in peoples' physical and perceptual experience (NUCKOLLS, 1996).

\footnotetext{
${ }^{1}$ MPhil (2003) e PhD (2009) em Linguística Aplicada pela Universidade de Bristol (Inglaterra), em que realizou Pós-Doutorado / Fundação Leonardo da Vinci (2009 - 2011) com verba da instituição Leonardo da Vinci. Estágio Pós-Doutoral através do Programa Nacional de Pós-Doutorado da Coordenação de Aperfeiçoamento de Pessoal de Nível Superior (PNPD/CAPES - 2014/2016), Brasil; na Universidade Federal de Pelotas (UFPEL), Brasil. Pesquisadora (2010-2011) do projeto BSL Learner Corpus - British Academy (UK). Professora da Universidade de Bristol (2007-2013) e diretora (2011-2013) da Greek School of Bristol em Bristol (Inglaterra). Email: maria.d.mertzani@gmail.com.
} 
Thus, KA is examined on the basis of diagrammatic iconicity, which is relational in nature. In other words, both forms (phoneme and grapheme) are considered as diagrams or icons that "represent the relations of the parts of one thing by analogous relations in their own parts" (WAUGH, 1994, p. 56), thus resembling and/or imitating objects in respect to the relations of their parts. On this basis, KA is considered non-arbitrary, in a systematic interdependence of elements in systems of meaning, and thus isomorphic with other cultural structures (e.g., art designs, cults).

It was hypothesised that symbolic mechanisms may underlie ancestral naming processes (CICCOTOSTO, 1991, p. 14). Thus, the more basic a word is, as the consonant-vowel (CV) form is, the more it may represent and contain a close connection between the symbol and the sensory event/object to be represented. In this study, shorter ${ }^{2}$ words appear in the CV form, based on the bi-phoneme synthesis of Linear B syllables. These are the base for word formation in Greek; bear a lexical content that in AG could occur on their own and function as independent words; and have a recursive character (RALLI, 2013, p. 9).

In this context, KA is explored as an initial syllable and hence, the root $^{3}$ of Greek and cognate language words. Word analysis involved the analysis of graphemes based on a close reading approach (KANEKO and SUTTON-SPENCE, 2011), which examined their features and structure in the words, and their associations with their referents. Where possible, their iconic properties were determined by their physical resemblance to their referents, and arbitrary free interpretation was avoided by advising established scholarship concerning ancient scripts and symbolism, and psycholinguistic research on symbolism. The approach involved the three-stage analogue-building model (TAUB, 2004) for demonstrating the relationship between the grapheme, its meaning and referent, following three stages: the image selection of a mental image that is associated with the original concept/referent; the schematisation of essential features of the image; and the encoding of the resulting schema, using the appropriate grapheme.

Since KA appears more frequently with the lateral syllable RA $(n=21 / 84)$, the paper discusses the iconicity of the combination KA-RA as a historical marker (cf. URBAN, 2009). The following section discusses the phonological iconicity of $/ \mathrm{k} /$ and $/ \mathrm{r} /$ in current psycholinguistic research and ancient scripts before presenting the findings.

\footnotetext{
${ }^{2}$ Overall, short words are considered more iconic (IWASAKI, VINSON and VIGLIOCCO, 2007), averagely they are more frequent, semantically they are more generic than the longer words, and the relationship between symbol-referent is analysed more easily and precisely "because their linguistic value depends on a smaller number of distinctive features" (NOBILE, 2011, p. 108). Additionally, the meanings of larger words reflect their composition and meanings, and within a language family (considering also the role of genealogical relationships or geographic neighbourhoods of languages in symbolism; cf. HAYNIE, BOWERN and LAPALOMBARA, 2014), similar units have similar attitudinal meanings crossculturally (HEISE, 1966, p. 14).

${ }^{3}$ Traditional linguistics defines as root the CVC form (BENGTSON and RUHLEN, 1994, p. 282; TAFT, 1979, p. 24).
} 


\section{VELAR AND LATERAL ICONICITY SINCE ANTIQUITY}

Since KA corresponds to velar phonemes of spoken languages and is a round grapheme, the study followed research that demonstrates their association with roundness. Similarly for laterals, since RA shows partial roundness through its iconic representation of a serpent and/or a flower (considering the cylindrical body of a snake and a bud). Following the Oxford English Dictionary (2017), roundness involves: (i) a circular surface, a disk, a circle; (ii) a curved shape like part of the circumference of a circle; (iii) a circular cross section, as a cylinder (cylindrical); (iv) a sphere or spherical/globular (e.g. a ball); (v) shaped more or less like a part of a sphere, hemispherical; (vi) full in physique, plump; and (vii) any hollowed-out space (e.g. a hole).

For example, in English, Magnus (2001) indicated the association of / $\mathrm{k} /$ with meanings of closure, containers and crevasses; and, /// and /r/ with words meaning round (e.g., loop, curl, and ball). In Japanese, the rolling motion is expressed through a combination of velar and lateral consonants with /o/ (e.g., goro: heavy object rolling; koro: light object rolling) (PERNISS, THOMPSON, and VIGLIOCCO, 2010). Furthermore, Spector and Maurer (2013) showed / k/ to appear in both angular and rounded shapes, a result that partially agrees with other research (KÖHLER, 1947; NIELSEN and RENDALL, 2011; NOBILE, 2015) indicating its link to jagged shapes when is combined with front vowels (e.g., /i/, /e/).

In terms of writing, Podgorny and Garner (1979) demonstrated the connection of / $/$ / with roundness through the graphemes $\langle\mathrm{C}\rangle$ and $\langle\mathrm{Q}\rangle$, a result repeated and confirmed by Changizi and Shimojo (2005). This is also constant with the AG representations of velars as: a semi-circle (modern C) gamma (JEFFERY, 1990, p. 79); an arrow or a cross (p. 89, 96), parts of Mycenaean KA; and koppa, the modern Q (p. 79) (Figure 2). In fact, this latter is exactly the same as the Mycenaean QA, which Evans (1909, p. 87) suggested to represent a roundish referent, a head ${ }^{4}$. Moreover, Evans $(1909 ; 1952)$ argued KA to represent the sun or an eye, round real-world referents too. These associations are shown in certain inscriptions for i.e., the goddess Cybele (WOODARD, 2014, p.17), the maiden daughter (ROBERTS and GARDNER, 1905, p. 438), and the solar wheel (VOUTYRAS, 2001, p. 220), where $<Q>$ is used instead of $<K>$.

In Egyptian hieroglyphs, the connection of velars to round referents is more evident due to their iconic (in their majority) nature. For example, /k/ is represented by a vessel, therefore demonstrating its association with meanings of closure and containers; /h/ with the sun and its radiance, an animal's head (e.g., of an ox), and/or a human face, pudenda muliebria, the horizon, and the nome (divided land). Additionally, in Luwian hieroglyphs, the syllable /ha/ is represented by a KA variation (Figure 3), and the velars /hu/ and /har/ with the logogram ANNUS are represented by vessels too (HAWKINS, 2000, p. 34, 64). Moreover, the logogram DEUS of a similar form to Mycenaean KA, also carries a velar value (p. 34). It is noted that KA used to be displayed on pottery, since early Neolithic, which was again interpreted as the sun to ensure the fertility

\footnotetext{
${ }^{4}$ In Sumerian pictographic the encircled cross is suggested to mean 'sheep' and 'ewe' (SCHMANDT-BESSERAT, 1996, p. 72).
} 
of the stored goods (URSULESCU and TENCARIU, 2009, p. 95). In Egyptian and Luwian hieroglyphs, laterals are depicted by symbols that represent the sun and the mouth, and thus real-world round referents.

Such symbolic correspondence also agrees with Munn (1966) who argued the use of round graphemes for roundish and non-elongate objects/phenomena (fire, waterhole, fruits etc.) on the graphic system of Walbiri. For example, a circle between two facing arcs may mean two persons sitting at a waterhole/at a fire, ancestors, and/or animals. Furthermore, it corroborates research that has examined the perception of certain concepts as round. For example, it is demonstrated that self, goodness, passiveness, affection, and warmth to be expressed as a circle and/or curve, whereas jagged, straight and angular shapes are found to convey threat, badness, activity/action, and speed (ARONOFF, 2006; HOMBERG, 1986). In Hiraga's (2006) study, roundness was feminine in words meaning small, light, and weak, and angularity masculine in the meanings large, heavy, and strong.

In line with these, the cross, encircled or not, represented the year as a journey of the sun embracing the four cardinal directions, denoting the cosmic cycle through all phases of the moon and the changing seasons, the recurrent birth and growth of plant, animal, and human life, and in Minoan and Mycenaean times, it was associated with the Great Goddess, whose worship involved the cross over crescents and horns (GIMBUTAS, 1982). This latter relationship is discussed in the next section.

\section{KA AND THE SYMBOLISM OF MOTHER EARTH}

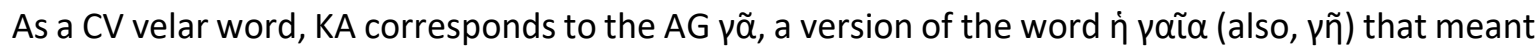
earth, land, ground, inclusive of water (the sea) and living organisms (the earth itself), which was linked to the Mother Goddess worship, as an exclamation to goddess Demeter in the phrase $\mu \tilde{\alpha}$ үã for $\mu \tilde{n} \tau \varepsilon \rho ~ ү \tilde{\eta}$ (mother earth). Such symbolism is constant with its meaning as it denotes the planet earth and thus, a round real-world referent, and with its round grapheme, which in antiquity (Greece, Egypt, China, etc.) was a broad symbol of earth (MERTZANI, 2015).

Based on Plutarch's account for the foundation of Rome (as a cyclical rite) in his Life of Romulus, its form corresponds to a circular city plan, divided into four parts by two main arteries, running from north to south, and west to east (urbs quadrata). As the three-stage analogue-building model shows (Figure 4), the description perfectly fits to the symbol itself; that is, the cross divides the circle in four quadrants. Other AG CV words (e.g., kă, downwards; kñ, there, in that place, in another world), also refer to meanings of earth, place and the underworld, thus corresponding to such symbolism.

In relation to Mother Earth, the circle of a city meant the vagina (HEALEY, 1977, p. 290), as a structured spatiality to contain or be contained, which currently is still manifested in the round physical structure of indigenous villages. Phonemically, this relationship is demonstrated in the equation yoĩ $-\alpha \tilde{i} \alpha$ (earth), where the closeness of gamma is equated with the centrality and roundness of /a/, depicting the 
space to contain or be contained (NOBILE, 2011, p. 114). Under this same meaning, the word 'Prín ${ }^{5}$ (Rhea) involves the same equation ( 1999).

The vagina in the worship of Mother Goddess (also known as Cybele, Kubela, Kubaba among other names) was represented by a cow and/or its horns (GIMBUTAS, 1989). For example, in Egyptian iconography, Mother Goddess Nut (RIGOGLIOSO, 2010, p. 28) is the cow with a star (the Venus star) between her horns (HOLBERG, 2007, p. 6-7). In fact, her genital area is depicted with the sun disk (WELLS, 1992, p. 306), and/or with the cow face (as Hathor) (BUDGE, 1904, p. 101), symbolising the summer triangle of Milky Way that marked the heliacal rising of the star Sirius and the consequent flooding of the Nile that fertilised earth. ${ }^{6}$ The sun disk corresponds to KA (as aforementoned), and the cow face to Mycenaean QA (Figure 5).

Mother Goddess was usually portrayed as a $\operatorname{cow}^{7}$ (in Greek, she is lo) or with horns on her head that represented also the moon as the lunar $\operatorname{sun}^{8}$ (GRAULICH et al., 1981; HEALEY, 1977) and primordial waters (GIMBUTAS, 1982; 1989), personifying the female organs. She was also depicted holding in her hands a libation bowl ${ }^{9}$ (B $\varnothing \mathrm{GH}, 2007$, p. 307), which symbolised the fruitfulness of woman, her womb as the vessel containing the seminal fluid from which a new being emerges (SMITH, 1919, p. 152). This latter relationship corresponds with the representation of $/ \mathrm{k} /$ as a vessel (see Figure 3), and with research connecting the concepts of water (WEBER, 2002, p. 25), mother and light (LIU and KENNEDY, 1997; LIU, 1997) with roundness.

In this symbolism, the earth is represented by the square, ${ }^{10}$ which in AG refers to the velar words кúßos, кú $\mu \beta \eta$, кú $\beta \eta$, кú $\beta \beta \eta$ (cube; head), and thus to the name of Mother Goddess Cybele; and the water by the cycle (GOLDSMITH, 1924, p. 4-5). Interestingly, the two dimensional form of KA involves these shapes, in particular, the three-dimensional pyramid (e.g., the cone) and/or the cube (WEBER, 2002, p. 20). Looking at

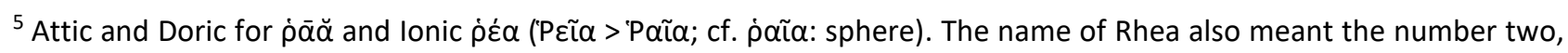
which is found in the Linear B RA (EVANS, 1952, p. 154-155) and archaic representation of lambda (JEFFERY, 1991, p.

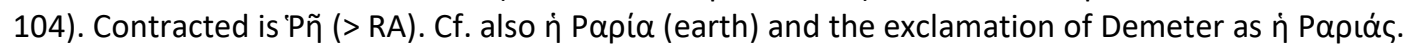

${ }^{6}$ The sun is only beneficent when the earth is moist with rain. "As the rain from heaven, then, caused things on earth to grow, it was natural that the main source of light and heat should be regarded as a male, and the earth as a female. As a male, the sun was supposed to have the emblems of virility, and a spouse whom he impregnated, and who thereby became fertile" (INMAN, 2005, p. xix).

${ }^{7}$ A cow-face, a crescent, or horns stood alike for Isis, Hathor, lo, Hera, or Demeter (ELWORTHY, 1895, p. 184), who were worshipped as Mother Goddesses. Io in the heroic age was considered to be the cow-goddess Hera herself. The Egyptian Isis was born at Argos, and she was identified with the cow lo, who was the same as Hera. Both were represented in Egypt and Greece with cows' horns (p. 182-183). In the religious mysteries of Argos, lo was the old name for the moon. “... [T] he cow horns of lo-Hera, who was also often represented with a cow's face, like that of Isis-Hathor, were derived from the symbolic horns of the crescent moon [...]" (p. 183).

${ }^{8}$ Venus, as the evening star, when visible at sunset, follows the sun over the horizon and behaves like the waxing moon, which placidly follows the sun to dip below the horizon at sunset (MAGINI, 2015, p. 29-31).

${ }^{9}$ The fluid or water was associated more especially with fertilisation by the male (ELWORTHY, 1895; SMITH, 1919).

${ }^{10}$ In ancient symbolism, the square alternates with the cycle. This alternation is preserved in Chinese writing (BOLTZ, 1994; DINGGUO, 2003).
} 
a pyramid from far above, its conical top is a small cycle/dot (the centre of the $\operatorname{cross}^{11}$ ), and from under it, the circle its base. This symbolism also corresponds to the meanings of Cybele's name as the mountain, the hollowness and/or the cavity (cf. ROLLER, 1994, p. 64). For example, there is diagrammatic analogy between the conical pyramid, the shape of the mountain (and the horn), and the shape of the vessel as a reverse hollow cone.

The fact that KA corresponds to both round (cycle) and angular shapes (cone), agrees with Spector \& Maurer (2013) who associated /k/ with round and angular referents, and with Miall (2001) and Nobile (2011) who connected /a/ with magnitude and largeness (e.g., under the meaning of land vastness). Interestingly, Cybele's name in Luwian hieroglyphs carries the grapheme DEUS (HAWKINS, 1981; 2000; ROLLER, 1999), which strongly resembles a variation of KA (the circle divided in two halves) (EVANS, 1952, P. 154; CHADWICK, 1987, p. 15), and earlier Minoan designs (Figure 6).

\section{THE SYMBOLISM OF KA-RA}

In line with this symbolic context, KA-RA combination was examined as a historical marker, since it has generated comparative core vocabulary, stable over millenia that associate with roundness. In particular, it was hypothesised that KA-RA words will associate with round referents and/or referents that carry qualities of roundness (see points i-vii of the definition), and with meanings that previous research finds to relate to roundness. Due to its laterality, RA stands for i.e., / kala/ and / kara/ words, ${ }^{12}$ whose meanings fall under seven semantic domains (Table 1) that correspond to Mother Earth meanings as well. In the Mycenaean corpus, KA-RA is met more frequently (unaspirated) under the meanings of earth/land and head/edge $(n=11 / 21)$, thus agreeing with the symbolism discussed above. Then, words meaning strength, light, cavity and vegetation follow $(n=9)$.

In AG, KA-RA produced words whose roundness is denoted on the shape of their referents, which resembles, in turn, the form of its round graphemes. For example, the word $\eta x \alpha \lambda \alpha$ (hoof) under the head/edge domain refers to an animal's roundish hoof, whose shape corresponds to the variations of KA (e.g., the circle divided in half), and the word $\eta \chi \alpha \rho \alpha$ (happiness, joy) corresponds to the roundness of an open mouth cavity during the physical act of i.e., smiling and laughing. Additionally, the word yóppa (rod) refers to an elongated referent of a cylindrical shape, hence agreeing with the dual symbolism of $/ \mathrm{k} /$ and roundness of $/ r /$. In relation to light (in terms of its spectrum), the combination refers to both lightness ( $ү a ́ d \alpha$ :

\footnotetext{
${ }^{11}$ The cross dividing the cycle in four quarters represents the sides of the pyramid. The base is square as well.

12 In cognate languages, KA-RA forms a rather large cluster of $/ \mathrm{gl} /$ words that share the meaning of light and liquids (HAYNIE, BOWERN and LAPALOMBARA, 2014), and /gr/ words that mean seizing and clutching; ground and vegetation; and negative emotions of terror, anger and hatred (SADOWSKI, 2001), which all agree with the meanings of this study in velars and laterals. Similarly, in Oceania and Southeast Asia languages, KA-RA words mean the sun, the eye and/or the face of the day (URBAN, 2009, p. 329). In relation to liquids, it means the milk (BENGTSON and RUHLEN, 1994, p. 308-309), and with regards to earth/land, the centre (e.g., warã) in the round construction of indigenous communities.
} 
white, the Milky Way) and darkness (Kóp: death), relating metonymically to the sun and moon, and hence to their life-cycle symbolism. In fact, these two words under the meanings of the Milky Way and death, remind of the Mother Goddess's symbolism as the galaxy and death itself.

Apart from head, the word kápa also meant the peak of a mountain, which also agrees with the symbolism discussed above in relation to Mother Goddess and KA (as the pyramid, mountain, and cone). In the light category, the word yó $\lambda \alpha v$ reminds her symbolism as the morning star, Venus, and the dawn $\dot{\eta}$ ä $\alpha \varsigma$

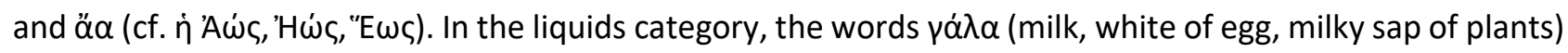
and kapás (emission of semen) indicate their connection to the symbolism of water (and liquids overall) as i.e., a serpent (cf. RA as a serpent), therefore also agreeing with psycholinguistic research that relates these two latter concepts to roundness.

\section{CONCLUSION}

Arbitrariness is challenged through the iconic cues of graphemes and phonemes within a given cultural schematisation, whose examination requires a comparative frame of evidence pertinent to interdisciplinary fields of archaeology, anthropology, gestalt psychology and linguistics. Following psycholinguistic research, the study demonstrated the relationship of KA-RA (as a historical masker) to roundness and to the concepts of earth/land, head/edge, cavity, light and liquids. Consisting of middle-toback phonemes $(/ \mathrm{a} /, / \mathrm{k} /, / \mathrm{r} /, / / /)$, and round graphemes, it maps to round real-world referents and to concepts perceived as round (e.g., light, water).

In relation to the ancient symbolism of Mother Goddess, it is shown that velar and lateral consonants (in combination with the centrality of $/ a /$ ) are used in the perception of nature and whole existence (e.g., motherhood) as feminine (cf. STARR SERED, 1994) and thus, as round, an outcome that agrees with previous research (cf. HIRAGA, 2006; LIU and KENNEDY, 1997; LIU, 1997). The specific phonemes and graphemes are culturally constructed, as they are manifested on the form of i.e., art designs that have been preserved and expressed in a similar fashion across civilizations (see Figure 5; cf. also /hara/ in Luwian hieroglyphs).

The study also adds depth to the iconicity of letters, challenging a well established arbitrary view of the alphabet. To present, the grapheme is understudied in linguistics, therefore it is necessary to describe it and include it in symbolism research, since its iconic nature provides visual cues about the meanings of words. In fact, the application of the analogue building model demonstrated that the overall cultural schematisation (e.g., art design on vases, city planning) is in close agreement with the form of the graphemes.

Concerning spoken languages, the iconicity involved Greek only, thus more data are necessary, phonemic and graphemic, involving comparisons among the shortest words across languages or language 
families for identifying any tendency or predisposition between certain phoneme-grapheme sequences and roundness.

\section{Funding Statement}

This research was funded by CAPES Foundation (Coordenação de Aperfeiçoamento de Pessoal de Nível Superior) for the Post-Doctoral Fellowship in CLC (Code: 42003016039P5). 


\section{REFERENCES}

ARONOFF, Joel. How we recognize angry and happy emotion in people, places, and things. Cross-Cultural Research, vol. 40, issue 1, p. 83-105, 2006.

BENGTSON, John D.; RUHLEN, Merritt. Global etymologies. In: RUHLEN, Merritt (Ed.). On the origin of languages: Studies in linguistic taxonomy. Stanford, California: Stanford University Press, 1994, p. 277336.

B $\varnothing \mathrm{GH}$, Birgitte. The Phrygian background of Kybele. Numen, vol. 54, p. 304-339, 2007.

BOLTZ, William G. The origin and early development of the Chinese writing system. New Haven: American Oriental Society (American Oriental Series, vol. 78), 1994.

BUDGE, Ernest Alfred Wallis. The gods of the Egyptians or studies in Egyptian mythology. Volume II. Chicago: Open Court Publishing Co, 1904.

CHANGIZI, Mark A.; SHIMOJO, Shinsuke. Character complexity and redundancy in writing systems over human history. Proceedings: Biological Sciences, vol. 272, issue 1560, 2005, p. 267-275.

CICCOTOSTO, NICK. Sound symbolism in natural languages. Unpublished doctoral dissertation, Graduate School, University of Florida, USA: Florida, 1991.

DINGGUO, GAO. Visual geometric properties in Chinese character processing: A behavioural and eventrelated potential study. Unpublished doctoral dissertation, University of Hong Kong, China: Hong Kong, 2003.

ELWORTHY, Frederick Thomas. The evil eye. An account of this ancient \& widespread superstition. London: John Murray, 1895.

EVANS, Arthur J. Scripta Minoa. Volume I. Oxford: Clarendon Press, 1909.

EVANS, Arthur J. Scripta Minoa. Volume II. Oxford: Clarendon Press, 1952.

GENETTE, Gérard. Mimologics. Lincoln \& London, USA: Nebraska University Press, 1995.

GIMBUTAS, Marija. The goddesses and gods of Old Europe 6500-3500 BC. Myths and cult images. Great Britain: Thames and Hudson, 1982.

GIMBUTAS, Marija. The language of the goddess. San Francisco: Harper \& Row Publishers, 1989.

GOLDSMITH, Elizabeth E. Life symbols as related to sex symbolism. New York: G.P. Putnam's Sons, 1924.

GRAULICH, Michel; CARRASCO, Pedro; COE, Michael D.; DURAND-FOREST, Jacqueline De ; GALINIER, Jacques

; GONZÁLEZ, Yólotl; et al. The metaphor of the day in ancient Mexican myth and ritual. Current Anthropology, vol. 22, issue 1, p. 45-60, 1981.

HAYNIE, Hannah; BOWERN, Claire; LAPALOMBARA, Hannah. Sound symbolism in the languages of Australia. PLOS ONE, vol. 9, issue 4, 2014.

HAWKINS, John David. Kubaba at Karkamiš and elsewhere. Anatolian Studies, vol. 31, p. 147-176, 1981. 
HAWKINS, John David. Corpus of hieroglyphic Luwian inscriptions. Volume I, Part 1. Inscriptions from the Iron Age. Berlin/New York: Walter de Gruyter, 2000.

HEALEY, Tim. The Symbolism of the cross in sacred and secular art. Leonardo, vol. 10, issue 4, p. 289-294, 1977.

HEISE, David R. Sound-meaning correlations among 1,000 English words. Language and Speech, vol. 9, issue 1, p. 14-27, 1966.

HINTON, Leanne; NICHOLS, Johanna; OHALA, John J. Introduction: Sound-symbolism processes. In: HINTON, Leanne; NICHOLS, Johanna; OHALA, John J. (Eds.). Sound symbolism. Cambridge, UK: Cambridge University Press, p. 1-12, 1994.

HIRAGA, Masako K. Kanji: The Visual Metaphor. Style, vol. 40, issue 1-2, p. 133-147, 2006.

HOLBERG, Jay B. Sirius: Brightest diamond in the night sky. Berlin: Springer - Praxis Publishing Ltd, 2007.

HOMBERG, Anna. On the visualization of some basic mental concepts. Empirical studies of the Arts, vol. 4, issue 2, p. 109-129, 1986.

INMAN, Thomas. Ancient pagan and modern Christian symbolism. New York, NY: Cosimo Inc., 2005.

IWASAKI Noriko; VINSON, David P.; VIGLIOCCO, Gabriella. What do English speakers know about gera-gera and yota-yota? : A cross-linguistic investigation of mimetic words for laughing and walking. Japanese Language Education around the Globe, vol. 17, p. 53-78, 2007.

JEFFERY, L.H. The local scripts of Greece. A study of the origin of the Greek alphabet and its development from the eighth to the fifth centuries B.C (Reissued with a supplement). Oxford: Clarendon Press, 1990.

KANEKO, Michiko; SUTTON-SPENCE, Rachel. Iconicity and metaphor in sign language poetry. Metaphor and Symbol, vol. 27, issue 2, p. 107-130, 2012.

KÖHLER, Wolfgang. Gestalt psychology (2nd ed.). New York, USA: Liveright, 1947.

LIU, Chang Hong. Symbols: cycles and spheres represent the same referents. Metaphor and Symbol, vol. 12, issue 2, p. 135 - 147, 1997.

LIU, Chang Hong; KENNEDY, John M. Form symbolism, analogy, and metaphor. Psychonomic Bulletin \& Review, vol. 4, issue 4, p. 546 - 551, 1997.

MAGINI, Leonardo. Stars, myths and rituals in Etruscan Rome. New York, NY: Springer, 2015.

MAGNUS, Margaret. What's in a word? Studies in phonosemantics. Unpublished doctoral dissertation, Norwegian University of Science and Technology, Trondheim, Norway, 2001.

MERTZANI, Maria. Symbolism of the encircled cross in Greece and Egypt. Paper presented at the XVI Jornada de História Antiga - Além das fronteiras: Contatos interculturais no Mediterrâneo Antigo, 24-28 August 2015. Laboratório de Estudos sobre a Cerâmica Antiga (LECA) - Polo Interdisciplinar de Estudos do Mundo Antigo (POIEMA), UFPEL, Pelotas, Brasil. August 27, 2015.

MUNN, Nancy D. Visual categories: An approach to the study of representational systems. American Anthropologist, vol. 68, issue 4, p. 936-950, 1966. 
NIELSEN, Alan; RENDALL, Drew. The sound of round: Evaluating the sound-symbolic role of consonants in the classic takete-maluma phenomenon. Canadian Journal of Experimental Psychology, vol. 65, issue 2, 2011, p. 115-124.

NOBILE, Luca. Words in the mirror: Analysing the sensorimotor interface between phonetics and semantics in Italian. IN: MICHELUCCI, Pascal; FISCHER, Olga; LUUNGBERG, Christina (Eds.). Iconicity in Language and Literature 10: Semblance and Signification. Amsterdam/Philadelphia: John Benjamins, 2011, p. 101-132.

NOBILE, Luca. Phonemes as images: An experimental inquiry into shape-sound symbolism applied to the distinctive features of French. In: HIRAGA, Masako K.; HERLOFSKY, William J.; SHINOHARA, Kazuko; AKITA, Kimi (Eds.). Iconocity: East meets West [Iconicity in Language and Literature 14], AmsterdamPhiladelphia: John Benjamins, 2015.

NUCKOLLS, Janis B. Sounds like life. Sound-symbolic grammar, performance and cognition in Pastaza Quechua. New York, Oxford: Oxford University Press, 1996.

OXFORD ENGLISH DICTIONARY. Oxford: Oxford University Press. Available at: <http://www.oed.com/>. 2017. PERNISS, Pamela; THOMPSON, Robin L.; VIGLIOCCO, Gabriella. Iconicity as a general property of language: Evidence from spoken and signed languages. Frontiers in Psychology, 2010.

PODGORNY, Peter; GARNER, W. R. Reaction time as a measure of inter- and intra object visual similarity: Letters of the alphabet. Perception \& Psychophysics, vol. 26, issue 1, p. 37-52, 1979.

RALLI, Angela. Compounding in Modern Greek. Dordrecht Heidelberg: Springer, 2013.

RIGOGLIOSO, Marguerite. Virgin Mother Goddesses of Antiquity. New York, NY: Palgrave Macmillan, 2010.

ROBERTS, Ernest Stewart; GARDNER, Ernest Arthur. An introduction to Greek epigraphy. Part II: the inscriptions of Attica. Cambridge: Cambridge University Press, 1905.

ROLLER, Lynn E. In search of god the mother. The cult of Anatolian Cybele. Berkeley, California: University of California Press, 1999.

SADOWSKI, Piotr. The sound-symbolic quality of word-initial "gr-cluster" in middle English alliterative verse. Neuphilologische Mitteilungen, vol. 102, issue 1, 37-47, 2001.

SCHMANDT-BESSERAT, Denise. How writing came about. Austin: University of Texas Press, 1996.

SMITH, G. Elliot. The evolution of the dragon. Manchester, UK: The University Press Longmans, Green \& Company, 1919.

SPECTOR, Ferrinne; MAURER, Daphne. Early sound symbolism for vowel sounds. i-Perception, vol. 4, p. 239$241,2013$.

STARR SERED, Susan. Priestess, mother, sacred sister. Religions dominated by women. New York, NY: Oxford University Press, 1994.

TAFT, Marcus. Lexical access via an orthographic code: The Basic Orthographic Syllabic Structure (BOSS). Journal of Verbal Learning and Verbal Behavior, vol. 18, p. 21-39, 1979. 
TAUB, Sarah F. Language from the body: Iconicity and metaphor in American Sign Language. Cambridge: Cambridge University Press, 2004.

TSELENTIS, Chris. Linear B lexicon [Pamphlet]. Athens, Greece: Attribution Non-Commercial ShareAlike (BYNC-SA), 2012.

URBAN, Matthias. 'Sun' and 'Moon' in the Circum-Pacific language area. Anthropological Linguistics, vol. 51, issue 3-4, p. 328-346, 2009.

URSULESCU, Nicolae; TENCARIU, Felix-Adrian. Symbolic signs on the ceramics of the Chalcolithic settlement from Isaiia (Iaşi county, Romania). In: Luca, S.A. (Ed.). Signs and Symbols from Danube Neolithic and Eneolithic. Proceedings from the International Symposium "The Danube Script: Neo-Eneolithic writing in Southeastern Europe," Sibium, May 18-20, 2008. Sibiu, Romania: Brukenthal National Museum, Institute of Archaeomythology, \& Institute for the Study \& Valorification of the Transylvanian Heritage in European Context, p. 87-101, 2009.

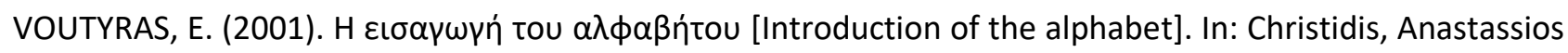

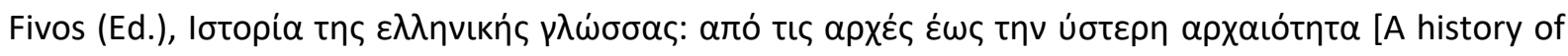
the Greek language: From the beginnings to late Antiquity]. Thessaloniki: Institute of Modern Greek Studies/Manolis Triantaphyllidis Foundation, p. 210-217, 2001.

WAUGH, Linda R. Degrees of iconicity in the lexicon. Journal of Pragmatics, vol. 22, p. 55-70, 1994.

WEBER, Jürgen. The judgement of the eye. The metamorphoses of geometry - One of the sources of visual perception and consciousness. Wien: Springer-Verlag, 2002.

WELLS, R.A. The mythology of Nut and the birth of Ra. Studien zur Altägyptischen Kultur, vol. 19, p. 305-321, 1992.

WOODARD, Roger D. The textualization of the Greek alphabet. New York: Cambridge University Press, 2014. 


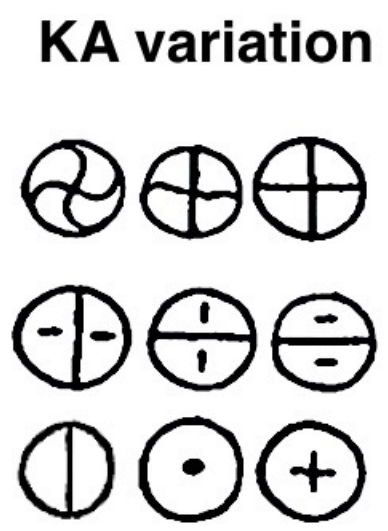

\section{Linear AB}

Figure 01: $K A$ and its variation in Linear $A B$ scripts

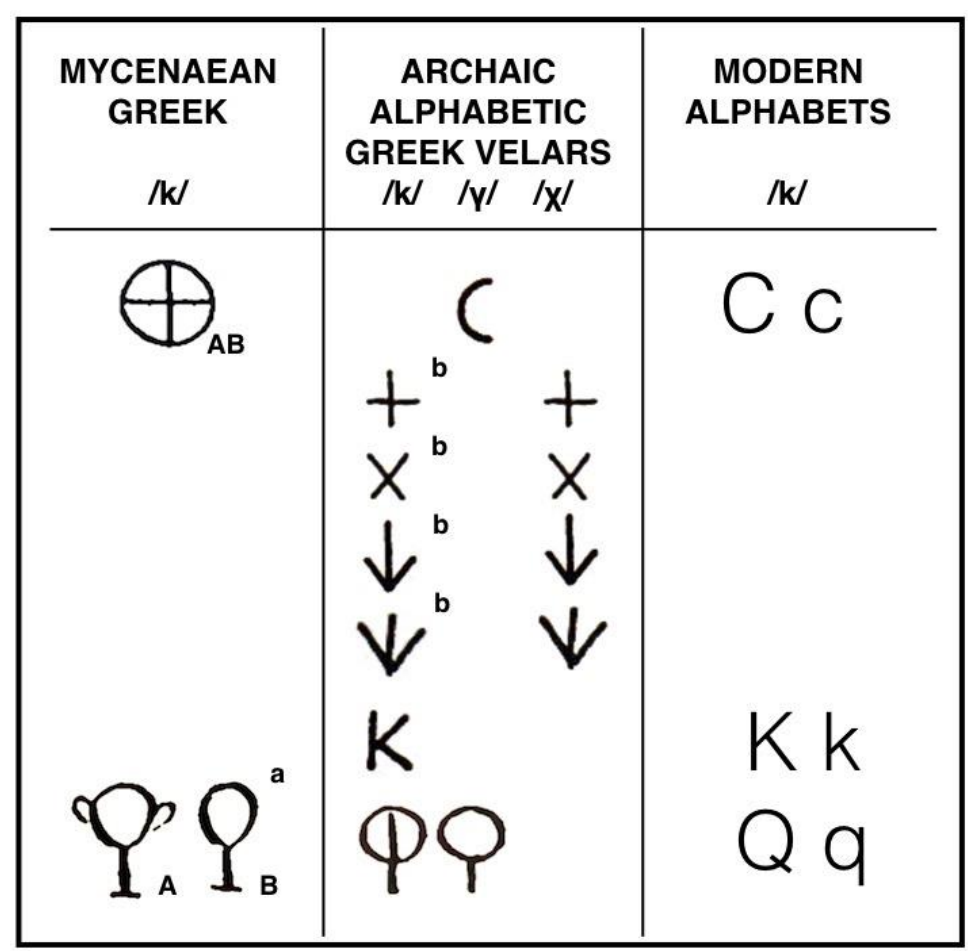

Figure 02: Velar consonants since Mycenaean Greek a) Symbol in Linear A (A) and in Linear B (B) or in both (AB). b) Symbols of the double phoneme /ks/ (MG: $\equiv, \xi)$, representing the phonemes /s/ and /k/. 
Egyptian Hieroglyphs

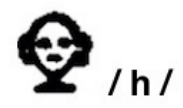

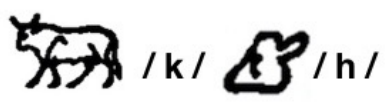

م

$\omega_{/ \mathrm{k} /}$
Linear AB Luwian Hieroglyphs

$\mathcal{Y}_{/ \mathrm{q} /}$

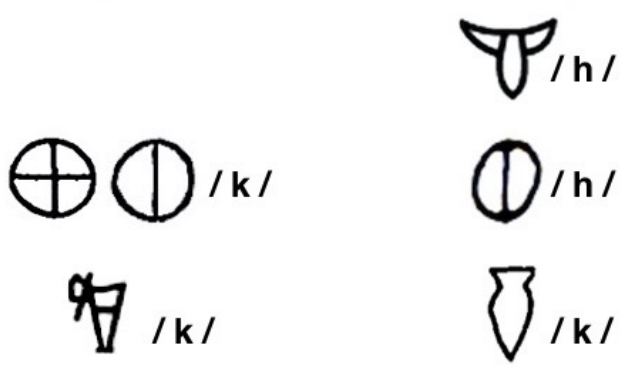

Figure 03: Analogies among velar phonemes and graphemes in ancient scripts. 


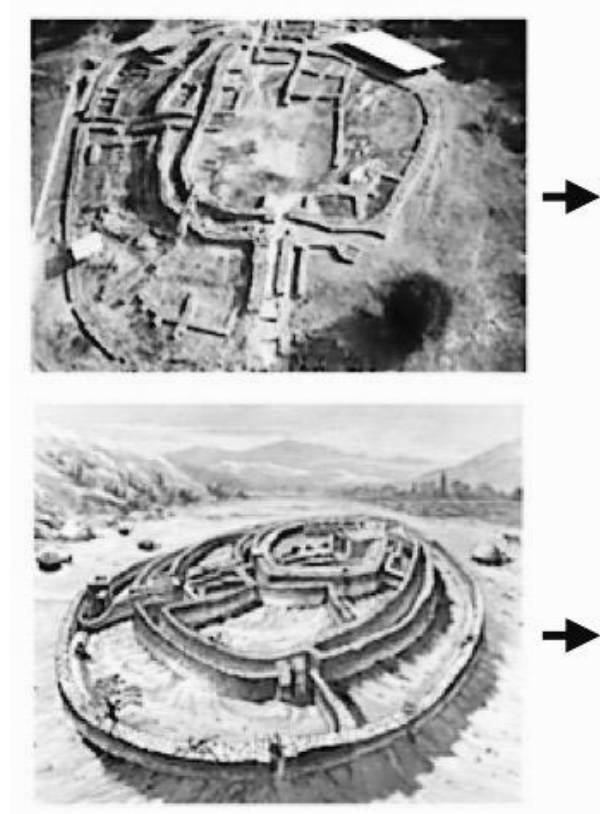

IMAGE SELECTION

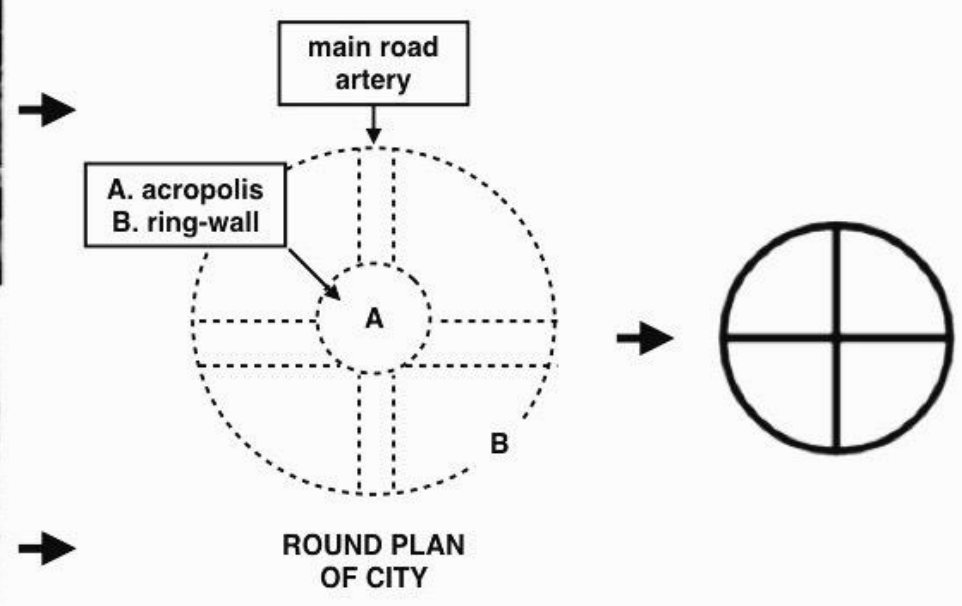

SCHEMATISATION

ENCODING: KA

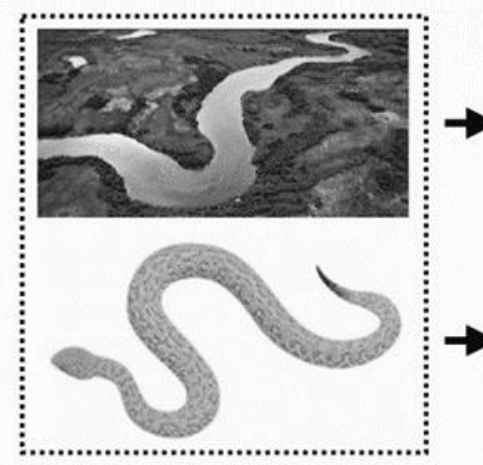

IMAGE SELECTION

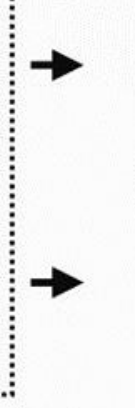

SCHEMATISATION

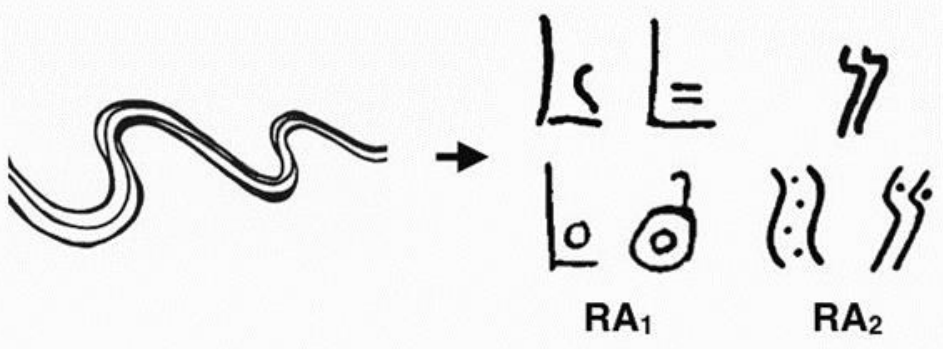

ENCODING: RA

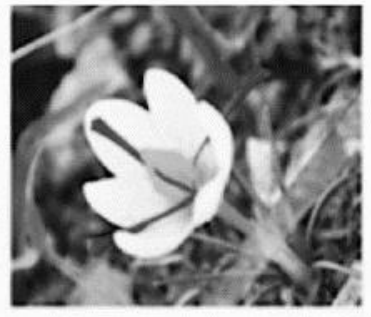

IMAGE SELECTION

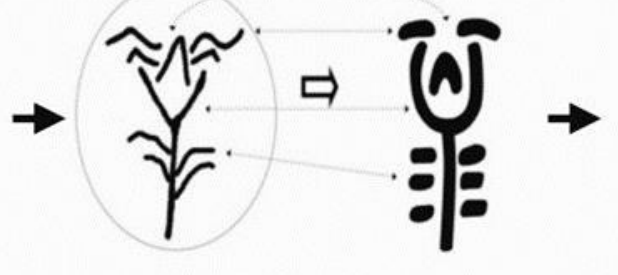

SCHEMATISATION

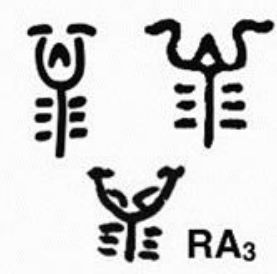

ENCODING: RA

Figure 4. The three-stage analogue-building model of KA-RA 

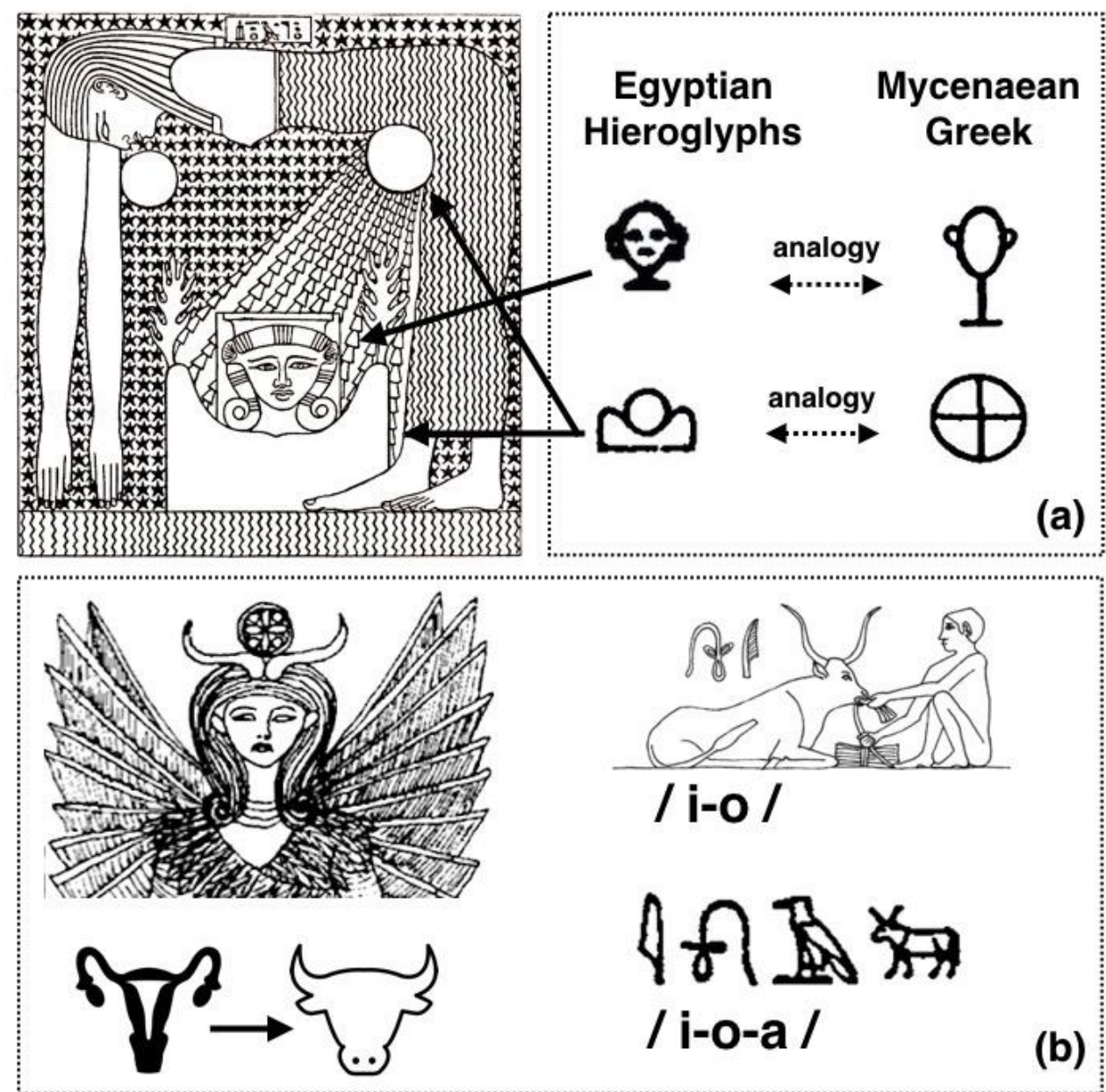

Figure 05: Analogies between the symbolism of Mother Goddess and ancient velar graphemes. a) The Linear AB QA in relation to the cow-face of the Mother Goddess; and KA in relation to her sun symbolism. b) The Mother Goddess as a cow, and/or a goddess having a cow-face, both representing female genitals and the pubic triangle.

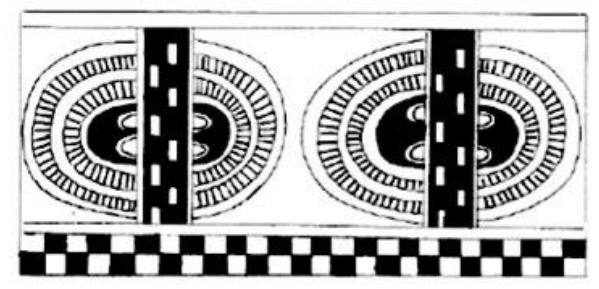

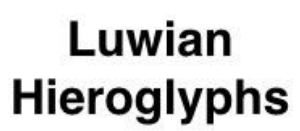

बह

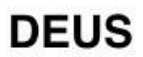

(1)

HA
Mycenaean

Greek

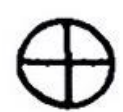

(1)

KA

\section{Minoan art designs}

Figure 06: Symbolic correspondences between Minoan art, Luwian DEUS/HA, and Mycenaean KA. 
Table 01: Examples of KA-RA Words in Greek

\begin{tabular}{|c|c|c|}
\hline KA-RA MEANINGS & MG WORDS & AG WORDS \\
\hline Earth & & үód $\alpha \varsigma$ (earth) \\
\hline Head, edge, top & $\begin{array}{l}\text { кó } \rho \alpha \\
\eta \chi \eta \lambda \eta ́\end{array}$ & 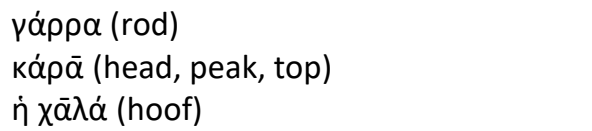 \\
\hline Loss, hurt, death & 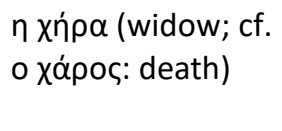 & $\begin{array}{l}\text { Ká } \rho \text { (death) } \\
\dot{\eta} \text { Kã } \rho, \text { Kń } \rho \text { (the goddess of death; doom, } \\
\text { death) }\end{array}$ \\
\hline Light, colours & 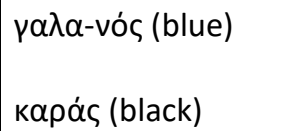 & 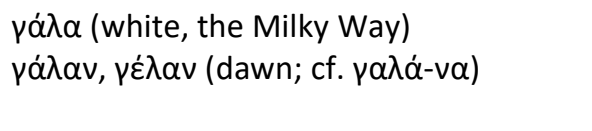 \\
\hline Liquids & үád $\alpha$ & 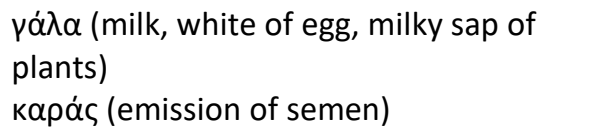 \\
\hline Goodness & $\begin{array}{l}\kappa \alpha \lambda \alpha \dot{\alpha}<\kappa \alpha \lambda \lambda i- \\
\eta \chi \alpha \rho \alpha \dot{\alpha}\end{array}$ & 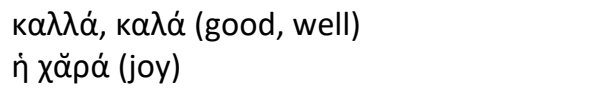 \\
\hline Life, vegetation & & 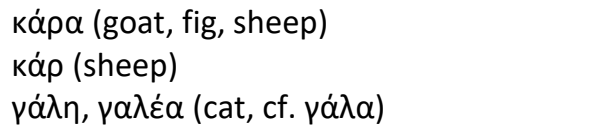 \\
\hline
\end{tabular}

